\title{
Soils of the Pacific \\ Northwest Shrub-Steppe. \\ Occurrence and Properties of Soils on The Arid Land Ecology Reserve, Hanford Reservation
}

R. E. Wildung

July 1977

Prepared for the Energy Research and Development Administration under Contract EY-76-C-06-1830 


\begin{tabular}{|c|c|}
\hline szots & $00 \varepsilon-9<2$ \\
\hline 00'0L5 & $S Z Z-L S Z$ \\
\hline $00 \cdot 65$ & $05 z-9 z z$ \\
\hline $5 \angle 8 \$$ & $S z z-L 0 z$ \\
\hline OS BS & $00 z-941$ \\
\hline SLLS & SLL-LSL \\
\hline $00 \angle S$ & $05 L-9 z t$ \\
\hline $05^{\prime} 95$ & $52 L-10 t$ \\
\hline $00 \% 95$ & $00 \mathrm{~L}-9 \angle 0$ \\
\hline 0S.SS & $S \angle O-\angle S O$ \\
\hline 00.55 & $050-920$ \\
\hline $0 s^{\prime}+5$ & $520-100$ \\
\hline फd รutÿs & sased. \\
\hline
\end{tabular}
SILN

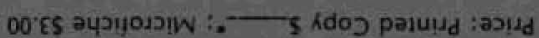

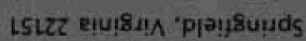

peoy gRKoy $\mu 0 d 58 z 5$

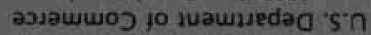

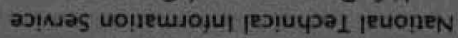

won ąqщuen

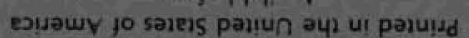

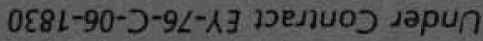

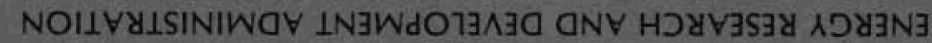 \\ วчt sof \\ эาาษนทg \\ Kq pajesado
}

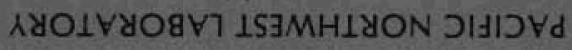

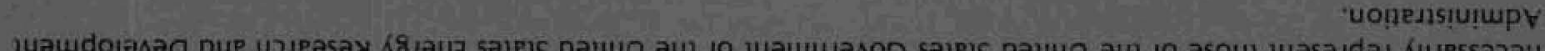
ajdas রiuessajay

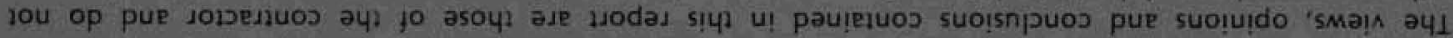

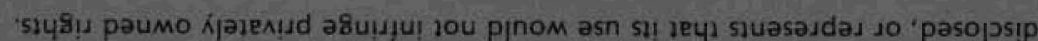

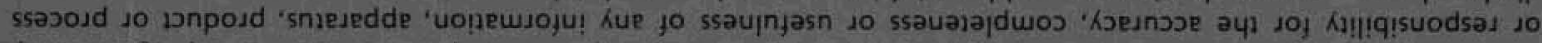

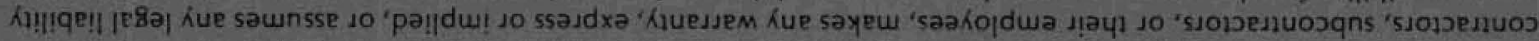

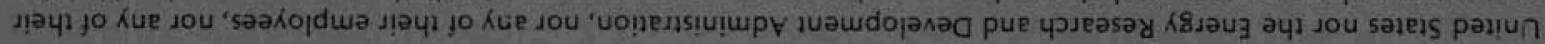

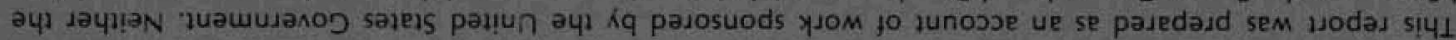

$3 \supset 110 \mathrm{~N}$ 
SOILS OF THE PACIFIC NORTHWEST

SHRUB-STEPPE. OCCURRENCE AND

PROPERTIES OF SOILS ON THE ARID

LAND ECOLOGY RESERVE, HANFORD

RESERVATION

R. E. Wildung

Ju1y 1977

BATTELLE

Pacific Northwest Laboratories

Richland, Washington 99352 
,

,

“

, 
The soils of the Arid Land Ecology Reserve, encompassing the IBP Grass1 and Biome intensive study site on the ERDA Hanford Reservation, are representative of a larger geographical region including much of the Columbia Plateau and Pacific Northwest shrub-steppe. This results from a unique diversity in (1) parent materials of mixed origin derived from the loess eolian, lacustrine and stream-laid material including glacial outwashes, river terraces, flood plains and alluvial fans and (2) meteorological factors accompanying a marked change in altitude within the Reserve resulting in development of soils over a range in temperature, moisture and vegetative regimes. The Reserve and the IBP Grassland Biome intensive study site serve as valuable, representative areas for the study of soil genesis and morphology in the shrub-steppe. The role of soils can be determined in basic environmental processes involving the flow of energy, cyclization of nutrients or the fate and behavior of pollutants. These processes may be examined to provide baseline information for comparison to other, more disturbed areas. Or, for investigative purposes, processes may be systematically altered to determine the influence of soil-perturbing activities such as agriculture, mining and industry on the terrestrial ecosystem. 
, 


\section{CONTENTS}

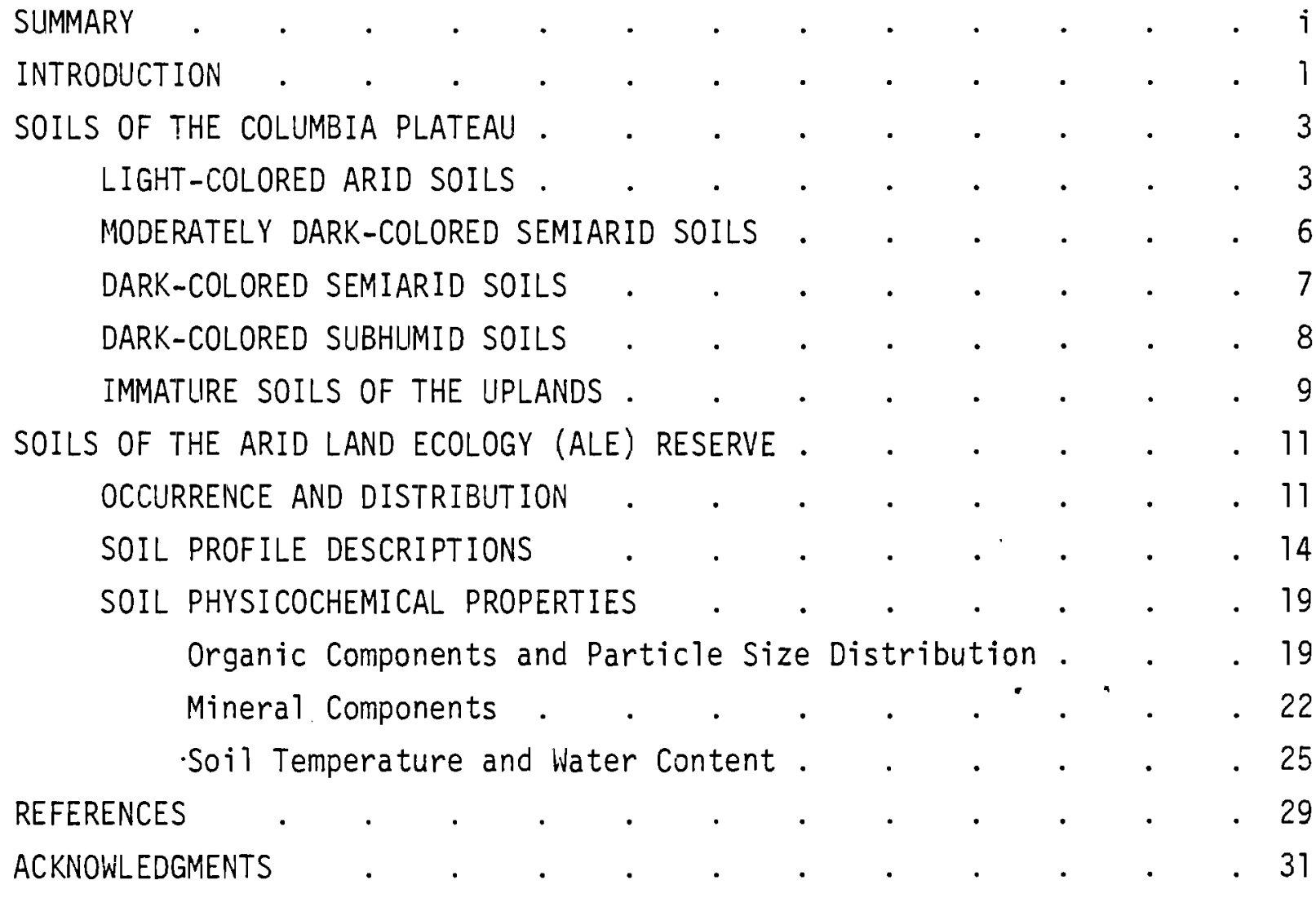




\section{FIGURES}

1. The Columbia Plateau in the Northwestern United States. . . 2

2. Distribution of soil associations on the Columbia Plateau . . 4

3. Soit Distribution on the Arid Land Ecology Reserve . . . 12

4. Seasonal Changes in Soil Temperature and Water Content

5. Moisture Tension Curves for Soils of the Arid Land Ecology Reserve . . . . . . . . . . 27

\section{$\underline{T A B L E S}$}

1. Representative Profile Description of the Lickskillet Loam . . 15

2. Representative Profile Description of the Ritzville Silt Loam . . . . . . . . . . . 16

3. Representative Profile Description of the Warden Sandy Loam . . . . . • . . • . . 17

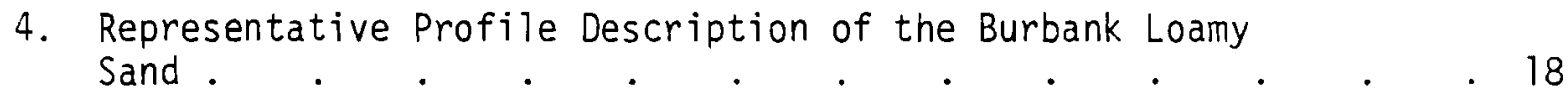

5a. Representative Soils of the Arid Land Ecology Reserve . . . 20

5b. Characteristics of Representative Soils of the Arid Land Ecology Reserve . . . . . . . . . . 20

6. Elemental Composition and Cation Exchange Capacity of Humic Acids from Representative Arid Land Ecology Reserve Soils . . . . . . . . . 22

7. Mineralogical Analys is of Representative Soils of the Arid Land Ecology Reserve . . . . . . . . 23

8. Quantity of Oxidic Iron, Aluminum, Manganese and Silicon in Representative Soils of the Arid Land Ecology Reserve . . 24 
SOILS OF THE PACIFIC NORTHWEST SHRUB-STEPPE. OCCUIRRENCE

AND PROPERTIES OF SOILS ON THE ARID LAND

ECOLOGY RESERVE, HANFORD RESERVATION

INTRODUCTION

The soil serves as an integral part of the grassland ecosystem and often plays a controlling role in its structure and function. The nature and extent of this role, however, is highly dependent upon soil physiocochemical and biological properties. These properties and the unique character of the soil in turn, are dependent upon the combined effects of the principal soilforming factors including its parent material, topography, climate, biological processes, time, and to a variable extent, man's activities.

This report describes the general occurrence and distribution of soils in the Pacific Northwest shrub-steppe as influenced by soil-forming factors, and details the formation and physicochemical properties of the soils in the vicinity of the Arid Land Ecology (ALE) Reserve and the International Biological Program (IBP) Grassland Biome intensive study site located on the Energy Research and Development Administration Hanford Reservation in Richland, Washington. It provides a general background for studies on specific soil processes and the basic ecology of the region.

The Pacific Northwest shrub-steppe encompasses vast acreages in the upland regions of eastern Washington, eastern Oregon, and southern Idaho and includes a diversity of soils. However, the soils of the shrub-steppe are typified by those existing on the Columbia Plateau, bordered by the northern Rocky Mountains on the east, the Cascade Mountains on the west, the Okanogan Highlands on the north and the Blue Mountains on the south (Figure 1). The plateau functions as a large inland basin comprised of a series of smaller basins. The surface of the plateau has been modified initially by glacial abrasion and redistribution and later by wind and water with a significant portion of the basin section developed on a mantle of loess and pleistocene outwash sediments. 


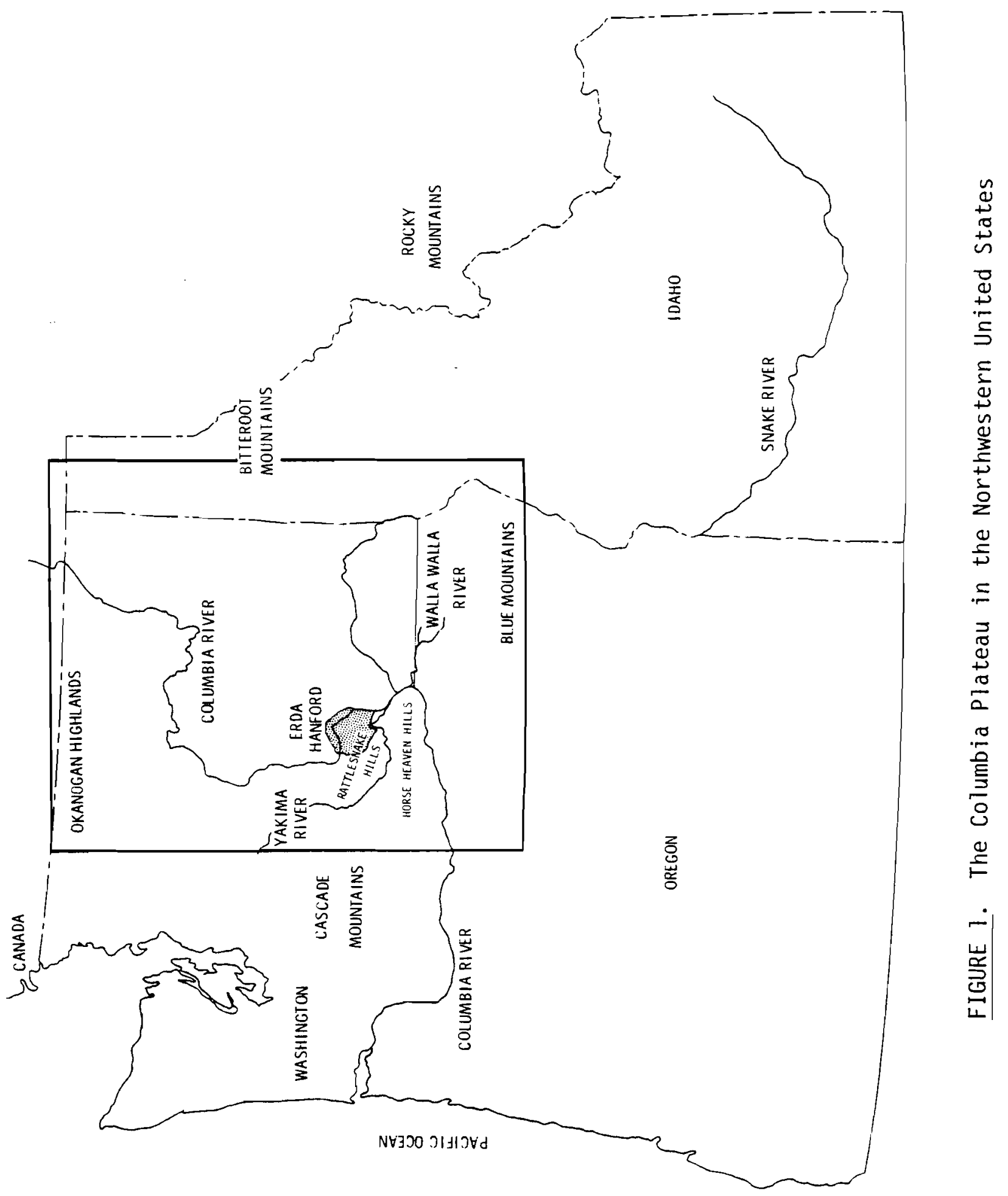




\section{SOILS OF THE COLUMBIA PLATEAU}

The soils of the Columbia Plateau supporting shrub-steppe vegetation are principally in the drier upland regions of 120 to 1,060 meters in eastern Washington, northwestern Idaho, and northern Oregon. The western edge of the plateau lies at lower elevation in the rainshadow of the Cascade Mountains which remove much of the precipitation from Pacific storms moving east. Soils of this region principally are Regosols and Sierozem associations. As precipitation increases to the east with increased elevation and distance from the Cascade Mountains, a gradation occurs to Brown and Chestnut soils in the central plateau and Chernozem and Prairie soils in eastern sections of the plateau and the foothills of the Bitteroot Mountains on the east and the Blue Mountains in the south. The Columbia Plateau is representative of much of the Pacific Northwest shrub-steppe and encompasses the vegetation of the Grassland Biome intensive study site. The general discussion of the plateau soils which follows is based on personal reconnais sance and on an excellent review of western soils by the Agricultural Experiment Stations of the Western States Land Grant Universities and Colleges with cooperative assistance by the Soil conservation Service, USDA (1964).

The soils of the Columbia Plateau may be generally classified as light-colored arid soils, moderately dark- and dark-colored semiarid soils, dark-colored subhumid soils, and immature soils of the uplands (Figure 2).

\section{LIGHT-COLORED ARID SOILS}

These desertic soils are generally confined to the center of the Columbia Plateau where elevations range from 250 to 330 meters. The climate is warm and dry with a mean annual temperature of 10 to $11^{\circ} \mathrm{C}$ and mean annual precipitation of 10 to $20 \mathrm{~cm}$, partially due to protection from storm movement from the west by the Cascade Mountains and from the south by basalt hills along the Columbia River gorge.

Soils of the Sierozem, Alluvial, and Solonchak association occupy terraces, alluvial fans and flood plains in the Yakima and Walla Walla River 


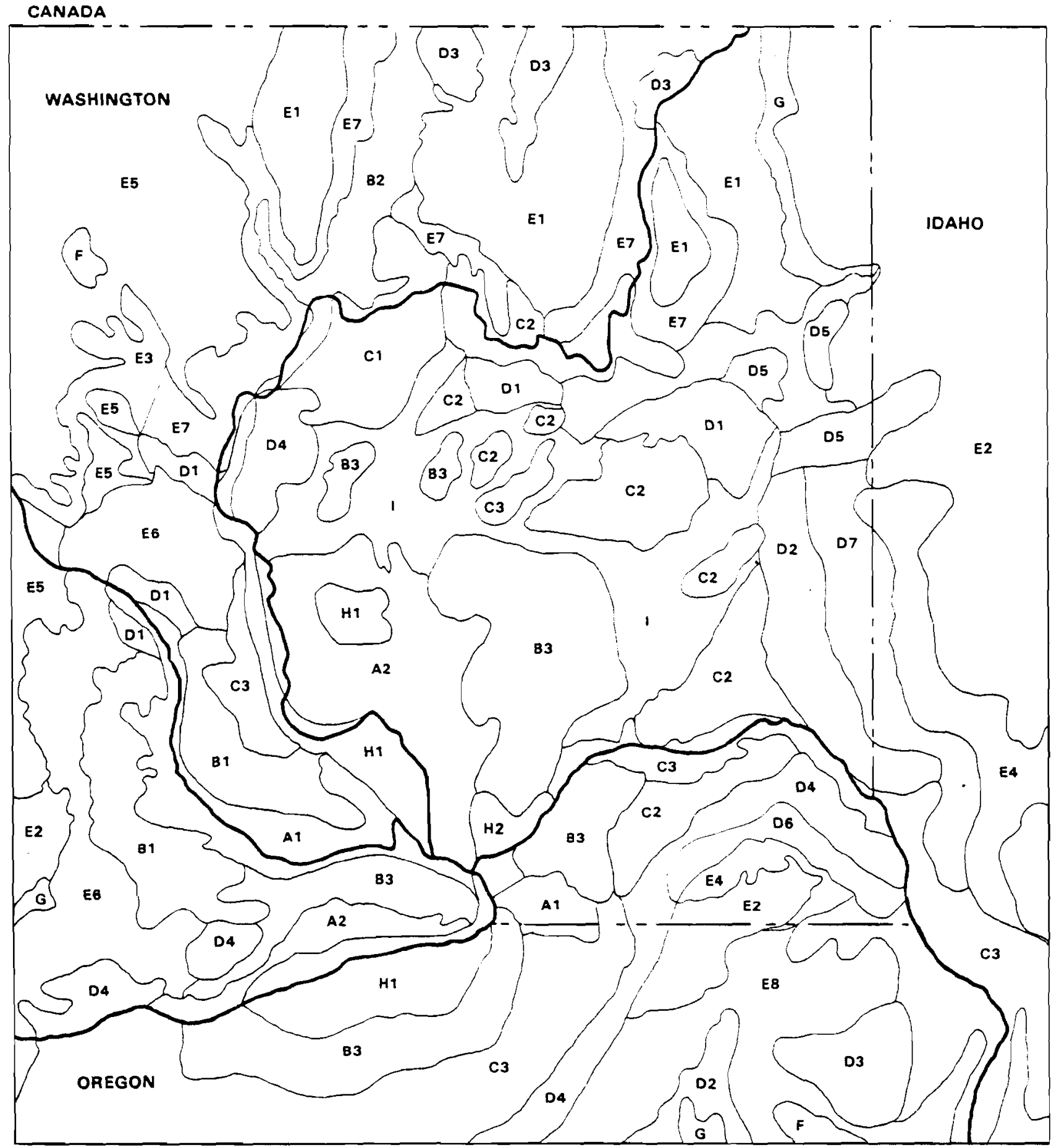

FIGURE 2. Distribution of soil associations on the Columbia Plateau (inset, Figure 1) (Modified from Soil Conservation Service, 1964). 


\section{LEGEND}

A LIGHT COLORED SOILS OF THE ARID REGIONS

1 Sierozem, Ailuvial, Solonchak.

2 Sierozem, Lithosol, Regosol.

B MODERATELY DARK COLORED SOILS OF THE SEMI-ARID REGIONS

1 Brown, Chestnut, Lithosol.

2 Brown, Lithosol, Alluvial.

3 Brown, Regosol, Lithosol.

C DARK COLORED SOILS OF THE SEMI-ARID REGIONS

1 Chestnut, Brown, Lithosol.

2 Chestnut, Chernozem, Solonetz.

3 Chestnut, Lithosol.

D DARK COLORED SOILS OF THE SUB-HUMID REGIONS

1 Chernozem, Chestnut, A1luvial.

2 Chernozem, Chestnut, Prairie.

3 Chernozem, Lithosol.

4 Chernozem, Prairie, Lithosol.

5 Prairie, Gray Brown Podzolic, Regosol.

6 Prairie, Lithosol.

7 Prairie, Planosol, Alluvial.

E SOILS OF THE COOL TO COLD, SUB-HUMID AND HUMID FORESTED REGIONS

1 Brown Podzolic, Gray wooded, Lithosol.

2 Brown Podzolic, Lithosol, Regosol.

3 Brown Podzolic, Podzol, Lithosol.

4 Gray Brown Podzolic, Western Brown Forest, Planosol.

5 Podzol, Brown Podzolic, Lithosol.

6 Western Brown Forest, Chestnut, Lithosol.

7 Western Brown Forest, Gray Wooded, Lithosol.

8 Western Brown Forest, Regosol, Lithosol.

$F$ SOILS OF THE COLD INONFORESTED MOUNTAIN REGIONS

Alpine Turf, Rockland, Alpine Meadow, Alpine Bog.

G RECENT ALLUVIAL SOILS

Humic Gley, Alluvial.

H IMMATURE SOILS ON UNCONSOLIDATED UPLAND MATERIALS AND EOLIAN SANDS

1 Regosol, Alluvial; Rockland.

2 Regosol, Brown.

I IMMATURE SHALLOW SOILS ON CONSOLIDATED UPLAND MATERIALS AND MISCELLANEOUS LAND TYPE

Lithosol, Chestnut, Brown. 
valleys. These alluvial and eolian (wind blown) deposits are derived from basalt andesite, sedimentary and granite rock sources and volcanic ash. Soils of the Sierozem, Lithosol, and Regosol association occupy terraces, glacial outwash plains, alluvial fans, benches, and mountain foothills east of the Columbia River in the central portion of the plateau often referred to as the Columbia Basin. They developed from alluvial deposits of shale, limestone, quartzite, sandstone, rhyolite granite, schist, and basalt sources.

These young soils developed under relatively low rainfall limiting leaching of salts to the $B$ horizon where carbonates may be accumulated at depths usually less than $60 \mathrm{~cm}$. Eluviation of clay generally does not occur. Vegetative cover is normally sparse and surface horizons usually contain less than 1.5\% organic matter. Erosion is common on these soils, particularly if soil surfaces are disturbed.

\section{MODERATELY DARK-COLORED SEMIARID SOILS}

Highly fertile, productive soils cover extensive areas of the Columbia Plateau at elevations above $300 \mathrm{~m}$ where the mean annual temperature range is 7 to $13^{\circ} \mathrm{C}$ and the mean annual precipitation is 20 to $44 \mathrm{~cm}$.

The brown soils dominate, but Lithosols and Regosols occupy a significant part of the landscape on the steeper slopes. Soils of the Brown, Chestnut, Lithosol association occupy plateaus, alluvial fans, terraces, and plains along the Rattlesnake Hills and the northern portion of the Horse Heaven Hills. These soils are derived from alluvium, colluvium, and residuum from basalt, rhyolite, tuff and sedimentary rock sources, pumice, and diatomite. Soils of the Brown, Regosol, and Lithosol association occupy plateaus, valley floors, benches, rolling hills and mountain slopes in the central plateau region and the southern portion of the Horse Heaven Hills. They are developed from residuum, colluvium, alluvium, loess, and outwash from sandstone, basalt, and lacustrine shale rock sources.

Soil formation processes are limited by low precipitation during the year, particularly long periods of summer drought and by freezing conditions during part of the winter. Organic matter content is usually less than $1.5 \%$ 
and reflects advanced stages of humification and limited organic matter production. Moisture may penetrate up to $100 \mathrm{~cm}$ and carbonate accumulation may extend to this depth. This occurs because most of the moisture comes during cooler portions of the year, limiting evapotranspiration and maximizing the quantities of moisture available for leaching. The soils are relatively young and the limited moisture and neutral to basic pH have led to eluviation of clay, mineral weathering and profile development.

\section{DARK-COLORED SEMIARID SOILS}

These soils generally reflect the moisture and temperature transition between the Brown soils of the dry, semiarid grasslands and the Chernozem soils of subhumid grasslands at elevations from 450 to $900 \mathrm{~m}$ where the mean annual precipitation is 30 to $50 \mathrm{~cm}$ and the mean annual temperature is 5 to $9^{\circ} \mathrm{C}$. The Chestnut soils dominate this zone in the Columbia Plateau. At the northern extreme, soils of the Chestnut, Brown, Lithosol association occupy plateaus, mountain slopes, breaks, glacial till plains, moranes, and outwash plains. They are developed principally on loess and residuum originating from basalt, rhyolite, tuff, shale, sandstone, and granite rock sources.

The Chestnut, Lithosol association predominates in the southwestern region along the west bank of the Columbia River north of the Rattlesnake Hills occupying plateaus, ridges, terraces, and flood plains. The Chestnut soils in the eastern section are associated with Chernozem and Solonetz soils and occupy loess hills, glaciated and nonglaciated plateaus, and glaciated valleys.

The Chestnut soils are characterized by higher organic matter content than the Brown soils but limited leaching of salts occurs principally because, although the surface soils receive higher annual precipitation, soil moisture is usually depleted by evapotranspiration processes in midsummer and the soils are seldom saturated to full profile depth. Soil profiles on the thick layer of loess in the eastern portion are relatively young and, with minimal leaching, are poorly differentiated, having little clay and weak calcium carbonate accumulations in the B horizon. 
These soils rim the northern, eastern, and southeastern sections of the Columbia Plateau at elevations ranging from 600 to 1200 meters where mean annual precipitation and temperatures range from 40 to $65 \mathrm{~cm}$ and from 5 to $9^{\circ} \mathrm{C}$, respectively. Although receiving more moisture and occupying a region of cooler temperatures than the soils discussed previously, these soils support the shrub-steppe vegetation typical of the other soils. However, the grasses of this region also include the forbs such as Festuca spp. The soil associations are relatively complex, but may be generally classified into the Chernozem and Prairie associations.

The Chernozem soils generally occur on loess hills, plateaus, terraces, and intermountain valleys at drier lower elevations adjacent to chèstnut and noncalcic Brown soils representing a transition between these soils and the Prairie soils. They are derived from loess, glacial outwash, and basalt, granite, sandstone, and shale rock sources. The Prairie soils in this region supporting shrub-steppe vegetation typically occur at wetter, higher elevations on loess hills, mountain slopes and terraces, and plateaus adjacent to forests which surround the plateau and in association with Lithosols. They are generally derived from the same parent materials as the Chernozems.

Although occurring over a wide range in annual precipitation and temperatures, the balance between these factors, particularly seasonal dry periods, generally results in grassland rather than forest vegetation on the Chernozem and Prairie soils. The luxuriant grassland in combination with cool temperatures result in maximum accumulations of organic matter. Base saturation is usually above $60 \%$. Clays have been elutriated often to considerable depth. The Chernozem soils which receive less moisture than the Prairie soils generally exhibit higher concentrations of organic matter in the surface horizons because while organic matter production is generally optimum in both soils, higher precipitation in the Prairie soils usually results in leaching of organic solubles from surface horizons. In the Chernozem, salts have not been leached from the B horizon, which may be slightly alkaline and contain calcium carbonate accumulations. In contrast, 
calcium carbonate is generally leached from the Prairie soil profiles, which are usually slightly acid, and the B horizons may contain higher clay concentrations through elutriative processes.

\section{IMMATURE SOILS OF THE UPLANDS}

The Columbia Plateau includes two principal areas of young soils of low fertility which support sparse shrub-steppe vegetation. Soils of these regions are dominantly Regosols and Lithosols.

The Regosols are generally located at low elevations of 90 to $300 \mathrm{~m}$ along the banks of the Columbia River and the Snake River near its confluence with the Columbia where the mean annual precipitation is 15 to 23 $\mathrm{cm}$ and the mean annual temperature is 11 to $12^{\circ} \mathrm{C}$. They include sandy, gravelly, wind-worked stream outwash deposits and occupy hummocky or undulating terraces and outwash plains developed from mixed alluvium; glacial outwash and eolian sands. As immature soils of relatively recent origin subject to low precipitation and sparse vegetation, the Regosols. largely reflect the properties of the parent material. They contain a weak A horizon, partially leached of salts, with low accumulations of organic matter, but lack a $B$ horizon.

The Lithosols are located in the northcentral part of the Columbia Plateau, generally at higher elevations, 300 to $1060 \mathrm{~m}$ where mean annual precipitation of 25 to $40 \mathrm{~cm}$ is higher and temperatures of 9 to $10^{\circ} \mathrm{C}$ are lower than in the river bottoms where the Regosols developed. The soils, usually in association with Brown and Chestnut soils, occupy plateaus, foothilis, and mountains and are derived from glacial outwash and from residuum and colluvium parent materials typical of the Brown and Chestnut soils. Lithosols are immature and shallow with only weakly developed, thin, often stoney, A horizons over parent material. Salt may be largely leached from this thin mantle of soil. 


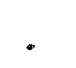




\section{SOILS OF THE ARID LAND ECOLOGY (ALE) RESERVE}

\section{OCCURRENCE AND DISTRIBUTION}

The ALE Reserve, part of the Energy Research and Development Administration, Hanford Reservation, encompasses the IBP intensive study site and is located on the northeast-facing slopes of the Rattlesnake Hills, adjacent to the Columbia River Plains, in southeastern Washington. The region is subject to low precipitation, as Pacific storms lose most of their moisture when air is cooled crossing the Cascade Mountains to the east. The presence of the Cascade Range also results in a lack of any moderating influence of the Pacific on temperatures which are high in the summer and low in the winter (Hinds and Thorp, 1969).

The ALE Reserve encompasses about 310 square kilometers with an upper elevation of $1,060 \mathrm{~m}$ at the crest of Rattlesnake Mountain which serves as the western boundary of the reserve. The northeast slope of Rattlesnake Mountain is abrupt, dropping to an elevation of $150 \mathrm{~m}$ on the adjacent plains where the eastern boundary of the reserve is located. This altitudinal gradient is responsible in part for differences on the reserve in mean annual temperature range of approximately 9 to $10^{\circ} \mathrm{C}$ and mean annual precipitation range of approximately 18 to $30 \mathrm{~cm}$. These factors, in conjunction with differences in parent material, have resulted in a diversity of soils in the vicinity of the IBP Grassland Biome intensive study site which is located at an elevation of $450 \mathrm{~m}$ on the northeast-facing slope of Rattlesnake Mountain.

The ALE Reserve lies in. the western portion of the Columbia Plateau and is underlain by a series of basaltic layers which are part of the Columbia River lava field (Figure 3). The lava is generally level in the valleys and plains but folded, steeply inclined layers form part of the canyon walls, benches, terraces, and rocky outcrops of the region. The basalt is often overlain by unconsolidated material which serves as the parent material for soils of the reserve. This includes materials of loessial, eolian lake-laid and stream-laid origin. 


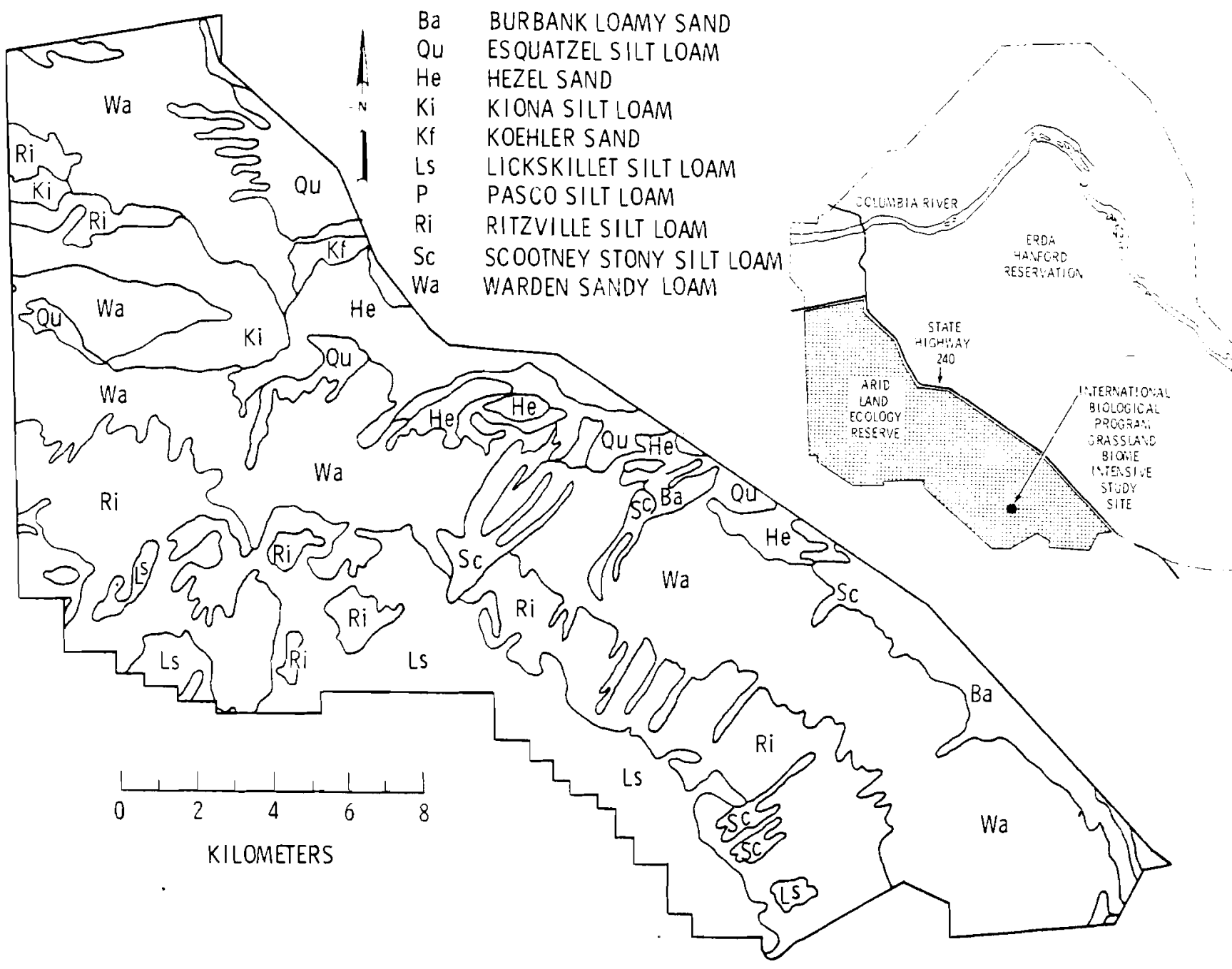

FIGURE 3. Soil Distribution on the Arid Land Ecology Reserve (Modified from Hajek, 1966).

The crest of Rattlesnake Mountain down to approximately $750 \mathrm{~m}$, consists principally of basalt overlain by a 25 to $50 \mathrm{~cm}$ layer of loess with numerous rocky outcrops and breaks. The relatively high precipitation and lower temperatures at this elevation have led to the presence of a variety of forbs as well as bluebunch wheatgrass. The combination of these factors has, in turn, resulted in very dark brown soils of up to $7 \%$ organic matter content for this region particularly in protected areas on the north face where snow fields may persist in the spring. The shallow nature of the soils, however necessitates classification as a Lithosol. These soils are typified by the Lickskillet series. 
Adjacent to the crest and extending to an elevation of approximately $180 \mathrm{~m}$, the soils which comprise the major portions of the ALE Reserve are derived from loess, usually greater than $150 \mathrm{~cm}$ deep, likely deposited when the velocity of westerly winds was reduced at the mountain crest. Above $360 \mathrm{~m}$, mean annual temperatures of $9^{\circ} \mathrm{C}$ and mean annual precipitation of 23 to $30 \mathrm{~cm}$ have led to the development of Brown soils underlain by basalt with dark, grayish-brown A horizons approximately $20 \mathrm{~cm}$ thick and a calcareous horizon below $90 \mathrm{~cm}$. These soils are typified by the Ritzville series on which the intensive study site is located. At approximately 360 $m$ elevation, the Brown soils grade to Sierozems which developed under a lower precipitation regime, 15 to $23 \mathrm{~cm}$, and perhaps higher temperatures. These soils, underlain by reworked lacustrine deposits, extend to a lower elevation of approximately $180 \mathrm{~m}$. They have been subjected to less leaching and a highly calcareous layer has developed at approximately $50 \mathrm{~cm}$. This soil is typified by the Warden series. Both the Brown and Serozem soils include occasional basalt outcrops.

At lower elevations on the north, eastern, and southern boundaries of the reserve, the soils are derived from lacustrine and stream-laid deposits which have been redistributed by wind. The mean annual precipitation here is 15 to $23 \mathrm{~cm}$ and the mean annual temperature is $10^{\circ} \mathrm{C}$. These soils, which do not occupy large areas of the ALE Reserve, are principally Regosols, Sierozems-Regosols intergrades or Alluvial soils.

The Regosols, typified by Burbank and Hezel series, are developed principally in unconsolidated wind-blown sands usually less than $100 \mathrm{~cm}$ deep and underlain by gravelly alluvium in the Burbank series or lacustrine sediments in the Hezel series. The latter soils occupy the largest portions of the nonloessial soils of the reserve. They are hummocky and the hummocks may be stabilized by shrubs and associated grasses. In the swards between hummocks, the underlying finer-textured sediments are often exposed by wind action in the late spring and early fall when overlying sands are dry. These soils are poorly developed, reflecting the properties of the parent material, but the slightly acidic surface horizons indicate some leaching of salts has occurred. 
The Sierozem-Regosol intergrade or Alluvial soils, typified by the Scootney series, lie in intermittent stream bottoms and alluvial fans from these streams. Although finer textured than the Regosols, they have weakly developed profiles, distinguishing them from the Warden series and are severely eroded.

The Alluvial soils are formed in recent alluvium derived from loess and lacustrine sediments. Surface horizons are very dark brown. Profile development is generally lacking on the ALE Reserve soils and the texture of the subsoil varies due to the stratified alluvium.

\section{SOIL PROFILE DESCRIPTIONS}

The soil profile descriptions for soils representative of the principal Great Soil Groups present on the ALE Reserve are outlined in Tables 1-4. They occur along an altitudinal transect of the northeast-facing slopes of the Rattlesnake Hills. The soils of the ALE Reserve were mapped in an early Bureau of Soils soil survey of Benton County (Kocher and Strahorn, 1916). However, the ALE Reserve, as part of the Hanford Reservation, was not included in the latest Benton County soil survey (Rasmussen, 1971) by the Soil Conservation Service. The representative profile descriptions are largely from the most recent survey, but are modified, as appropriate, to more precisely reflect the profiles of the noncultivated soils on the ALE Reserve.

The Lickskillet loam (Table 1), a Lithosol, is located at the crest of the Rattlesnake Hills. It is stoney, containing numerous basalt fragments and is located among basalt rock outcrops. The shrub species is big sagebrush, Artemisia tridentata, present at low density, whereas the understory consists primarily of bluebunch wheatgrass, Apropyron spicatum and low growing forbs, e.g., Festuca spp., typical of Prairie soils.

The Ritzville silt loam (Table 2), a Brown-Regosol intergrade, is generally located at elevations between the Lickskillet loam, at higher elevations, and the warden sandy loam, at lower elevations. It overlays basalt bedrock as in the case of the Lickskillet, but it is deeper than the 
TABLE 1. Representative Profile Description of the Lickskillet Loam (modified from Rasmussen, 1971)

\begin{tabular}{|c|c|}
\hline Horizon & Description \\
\hline $\mathrm{Al}$ & $\begin{array}{l}0 \text { to } 5 \text { inches, very dark brown (10YR } 2 / 2) \text { very } \\
\text { stony silt loam, grayish brown (10YR } 5 / 2) \text { when } \\
\text { dry; weak, fine, granular structure; soft, } \\
\text { friable, slightly sticky and slightly plastic; } \\
\text { abundant roots; many, fine, vesicular pores; } \\
\text { slightly acid (pH } 6.2) \text {; about } 10 \text { percent basalt } \\
\text { fragments; gradual, wavy boundary. } 2 \text { to } 8 \\
\text { inches thick. }\end{array}$ \\
\hline B21 & $\begin{array}{l}5 \text { to } 11 \text { inches, dark-brown (10YR } 3 / 3 \text { ), very } \\
\text { stony heavy silt loam, brown (10YR } 5 / 3 \text { ) when } \\
\text { dry; moderate, medium, subangular blocky struc- } \\
\text { ture; few thin coatings on ped surfaces; } \\
\text { slightly hard, friable, sticky and plastic; } \\
\text { plentiful roots; common fine pores; slightly } \\
\text { acid (pH } 6.5 \text { ); approximately } 40 \text { percent } \\
\text { basalt fragments; gradual, wavy boundary. } 3 \\
\text { to } 10 \text { inches thick. }\end{array}$ \\
\hline B22 & $\begin{array}{l}11 \text { to } 18 \text { inches, dark yellowish-brown (10YR } \\
3 / 4 \text { ), very stony heavy silt loam, yellowish } \\
\text { brown (10YR 5/4) when dry; moderate, medium, } \\
\text { subangular blocky structure; few thin coatings } \\
\text { on ped surfaces; slightly hard, friable, } \\
\text { sticky and plastic; plentiful roots; common } \\
\text { fine pores; may be mildly alkaline (pH } 7.8 \text { ); } \\
\text { approximately } 60 \text { percent angular basalt frag- } \\
\text { ments; abrupt, irregular boundary. } 5 \text { to } 12 \\
\text { inches thick. }\end{array}$ \\
\hline
\end{tabular}

IIR $\quad 18$ inches, basalt bedrock with some fractures. The rock fractures are coated with limesilica and contain matted roots.

The texture of the $B$ horizon ranges from heavy silt loam to silty clay loam. The stoniness and the number of rock outcrops varies widely within short distances. The depth to basalt bedrock ranges from 10 to 20 inches; the average depth is about 18 inches. 
TABLE 2. Representative Profile Description of the Ritzvilie Silt Loam (modified from Rasmussen, 1971)

\begin{tabular}{|c|c|}
\hline Horizon & Description \\
\hline A1 & $\begin{array}{l}0 \text { to } 8 \text { inches, very dark grayish-brown (10YR } \\
3 / 2 \text { ) silt loam, grayish brown (10YR } 5 / 2 \text { ) when } \\
\text { dry; weak, coarse granular structure; soft, } \\
\text { friable, nonsticky and slightly plastic; } \\
\text { abundant roots; common fine oores; slightly } \\
\text { acid (pH } 6.2 \text { ); gradual, smooth boundary. } \\
6 \text { to } 15 \text { inches thick. }\end{array}$ \\
\hline$B 2$ & $\begin{array}{l}8 \text { to } 36 \text { inches, dark-brown (10YR } 3 / 3 \text { ) silt } \\
\text { loam, brown (10yR 5/3) when dry; weak, coarse, } \\
\text { prismatic structure; soft, friable, non- } \\
\text { sticky and slightly plastic; few roots; com- } \\
\text { mon fine pores; mildly alkaline ( } \mathrm{pH} 7.6 \text { ); } \\
\text { abrupt, wavy boundary. } 10 \text { to } 25 \text { inches } \\
\text { thick. }\end{array}$ \\
\hline Clca & $\begin{array}{l}36 \text { to } 51 \text { inches, dark grayish-brown (10YR } \\
4 / 2 \text { ) silt loam, light brownish gray (10YR } \\
6 / 2 \text { ) when dry; weak, coarse, prismatic struc- } \\
\text { ture; soft, friable, nonsticky and slightly } \\
\text { plastic; few roots; common fine pores; strong } \\
\text { effervescence; moderately alkaline (pH } 8.2 \text { ); } \\
\text { gradual, wavy boundary. } 6 \text { to } 20 \text { inches thick. }\end{array}$ \\
\hline C2ca & $\begin{array}{l}51 \text { to } 67 \text { inches, dark grayish-brown (10YR } \\
4 / 2) \text { silt loam, light brownish gray (10YR } \\
6 / 2) \text { when dry; massive; slightly hard, firm, } \\
\text { nonsticky and slightly plastic; few roots; } \\
\text { common fine pores; violent effervescence; } \\
\text { moderately alkaline (pH } 8.4) \text {. }\end{array}$ \\
\hline \multicolumn{2}{|c|}{$\begin{array}{l}\text { Generally, the depth to bedrock is more than } 50 \text { inches, but in } \\
\text { places it is as littie as } 30 \text { inches and occasional rock out- } \\
\text { croos occur principaliy at the edges of gullies. The depth to } \\
\text { lime is commonly more than } 36 \text { inches, but it is less than } 36 \\
\text { inches in some of the areas where bedrock is within } 60 \text { inches } \\
\text { of the surface. A significant portion of the surface is occu- } \\
\text { pied by lichen mats which tend to stabilize the soit to wind } \\
\text { erosion. The soil is well drained. Firm aggregates of silt } \\
\text { from overlying horizons have been deposited in insect burrows. } \\
\text { These aggregates are as much as } 1 / 2 \text { inch wide and } 4 \text { inches } \\
\text { long. They are common in the } C \text { horizon. }\end{array}$} \\
\hline
\end{tabular}


TABLE 3. Representative Profile Description of the Warden Sandy Loam (modified from Rasmussen, 1971)

\begin{tabular}{|c|c|}
\hline Horizon & Description \\
\hline $\mathrm{AT}$ & $\begin{array}{l}0 \text { to } 9 \text { inches, dark grayish-brown (10YR } 4 / 2) \\
\text { sandy loam, light brownish gray (10YR } 6 / 2 \text { ) when } \\
\text { dry; weak coarse granular structure; slightly } \\
\text { hard, friable, nonsticky and slightly plastic; } \\
\text { abundant roots; common fine tubular pores; } \\
\text { neutral (pH } 7.0) \text {; gradual, smooth boundary. } \\
0 \text { to } 3 \text { inches thick. }\end{array}$ \\
\hline$B 2$ & $\begin{array}{l}9 \text { to } 19 \text { inches, dark grayish-brown }(10 \text { YR } 4 / 2) \\
\text { silt loam, light brownish gray (10YR } 6 / 2) \text { when } \\
\text { dry; weak, medium, subangular blocky structure; } \\
\text { soft, friable, slightly sticky and slight } 1 \text { y } \\
\text { plastic; plentiful roots; common fine tubular } \\
\text { pores; mildly alkaline (DH } 7.6) \text {; abrupt, wavy } \\
\text { boundary. } 10 \text { to } 20 \text { inches thick. }\end{array}$ \\
\hline IIClca & $\begin{array}{l}19 \text { to } 29 \text { inches, grayish-brown }(2.5 Y \text { 5/2) silt } \\
\text { loam, light brownish gray }(2.5 Y 6 / 2) \text { when dry; } \\
\text { massive; slightly hard, friable, slightly sticky } \\
\text { and slightiy plastic; plentiful roots; common } \\
\text { fine tubular pores; violent effervescence; } \\
\text { moderately alkaline (pH } 8.4) \text {; gradual, wavy } \\
\text { boundary. 8 to } 15 \text { inches thick. }\end{array}$ \\
\hline I IC2ca & $\begin{array}{l}29 \text { to } 51 \text { inches, brown (loYR } 5 / 3 \text { ) silt loam, pale } \\
\text { brown (10YR } 6 / 3 \text { ) when dry; finely laminated, } \\
\text { slightly hard, friable, slightly sticky and } \\
\text { slightly plastic; plentiful roots; common fine } \\
\text { tubular pores; disseminated and segregated } \\
\text { mycelial lime; violent effervescence; moderately } \\
\text { alkaline (pH } 8.4 \text { ); gradual, wavy boundary. } \\
\text { Variable thickness. }\end{array}$ \\
\hline I IC $3 \mathrm{ca}$ & $\begin{array}{l}51 \text { to } 60 \text { inches, grayish-brown }(2.5 Y \text { 5/2) silt } \\
\text { loam, light brownish gray }(2.5 Y \text { \% } 6 / 2) \text { when dry; } \\
\text { massive; slightly hard, friable, slightly sticky } \\
\text { and slightly plastic; disseminated and segregated } \\
\text { mycelial lime; violent effervescence; moderately } \\
\text { alkaline (pH } 8.4) \text {. }\end{array}$ \\
\hline
\end{tabular}

The texture may vary from a fine sandy loam to a silt loam. Includes small areas of Hezel fine sand. In places the horizon is stratified with loamy sand. The depth to the calcareous layer is commonly about 27 inches. The depth to bedrock is more than 60 inches in most places, but it is about 40 inches in some areas. In places granite cobbles are present. 
TABLE 4. Representative Profile Description of the Burbank Loamy Sand (modified from Rasmussen, 1971)

\begin{tabular}{|c|c|}
\hline Horizon & Description \\
\hline $\mathrm{Cl}$ & $\begin{array}{l}0 \text { to } 5 \text { inches, very dark grayish-brown (1OYR } \\
3 / 2 \text { ) loamy fine sand, grayish brown (10YR 5/2) } \\
\text { when dry; single grain; loose, nonsticky and } \\
\text { nonplastic; abundant roots; neutral ( } 10.9 \text { ); } \\
\text { gradual, wavy boundary. 0 to } 5 \text { inches thick. }\end{array}$ \\
\hline $\mathrm{C} 2$ & $\begin{array}{l}5 \text { to } 16 \text { inches, very dark grayish-brown (10YR } \\
3 / 2 \text { ) loamy sand, grayish brown (10YR 5/2) when } \\
\text { dry; single grain; loose, nonsticky and non- } \\
\text { plastic; few roots; mildiy alkaline (pH } 7.6) \text {; } \\
\text { gradual, wavy boundary. } 10 \text { to } 30 \text { inches thick. }\end{array}$ \\
\hline IIC3 & $\begin{array}{l}16 \text { to } 30 \text { inches, very dark grayish-brown (10YR } \\
3 / 2) \text { gravelly loamy sand, light brownish gray } \\
(10 \text { YR 6/2) when dry; single grain; loose, non- } \\
\text { sticky and nonplastic; few roots; mildly alka- } \\
\text { line (pH } 7.8) \text {; strong effervescence; about } \\
45 \text { percent gravel, some of which is coated with } \\
\text { lime-silica on the lower side; abrupt, wavy } \\
\text { boundary. } 10 \text { to } 20 \text { inches thick. }\end{array}$ \\
\hline IIIC4ca & $\begin{array}{l}30 \text { to } 35 \text { inches, dark grayish-brown (10YR } 4 / 2 \text { ) } \\
\text { very gravelly loamy sand, light brownish gray } \\
\text { (10YR 6/2) when dry; single grain; loose, non- } \\
\text { sticky and nonplastic; moderately alkaline } \\
\text { (pH } 8.3 \text { ); violent effervescence; about } 85 \text { per- } \\
\text { cent gravel and stones; some of the fragments } \\
\text { are completely coated with lime-silica; gradual } \\
\text { wavy boundary. } 4 \text { to } 20 \text { inches thick. }\end{array}$ \\
\hline IIIC5 & 35 to 60 inches, sandy gravel. \\
\hline \multicolumn{2}{|c|}{$\begin{array}{l}\text { In some places the Cca horizon is sufficiently developed that } \\
\text { the gravel and stones are weakly cemented by lime and silica. } \\
\text { The depth to sandy gravel is more than } 20 \text { inches. In places } \\
\text { a layer of gravelly fine sandy loam, } 2 \text { to } 6 \text { inches thick, } \\
\text { directly overlies the sandy gravel. Gravel makes up less than } \\
50 \text { percent of the Cca horizon in a few places. }\end{array}$} \\
\hline
\end{tabular}


Lickskillet and contains less organic matter in the surface horizons. The vegetation consists of Artemisia tridentata, in generally higher density than the Lickskillet and Agropyron spicatum. Forbs generally do not represent a significant part of the total aboveground biomass.

The Warden sandy loam (Table 3), a Sierozem-Regosol intergrade, is located adjacent to the Ritzville at lower elevations near the base of the Rattlesnake Hills above the basel plains. It is usually greater than $150 \mathrm{~cm}$ deep and overlays lacustrine deposits known as the Ringold sediments. The principal shrub species is Artemisia tridenta but, in contrast to the Ritzville, the primary understory is Sandberg bluegrass, Poa secunda.

The Burbank loamy sand (Table 4), a Regosol, occupies the basel plains of the ALE Reserve adjacent to the Warden and in geographical association with the Hezel sand and the Esquatzel silt loam. It includes areas previously classifed (Kocher and Strahorn, 1916; Hajek, 1966) as Ephrata. The soil developed in stoney alluvial deposits mantled with mixed alluvium and windblown sand. The principal shrub species is Artemisia tridentata and the understory consists primarily of cheatgrass, Bromus tectorum.

\section{SOIL PHYSICOCHEMICAL PROPERTIES}

The principal characteristics (Wildung et al., 1971) of the soils along a $13 \mathrm{~km}$ altitudinal transect from 155 to $1060 \mathrm{~m}$ elevation on the northeastfacing slopes of the Rattlesnake Hills are sumarized in Tables $5 \mathrm{a}, 5 \mathrm{~b}$. The sampling sites on the ALE Reserve were selected on the basis of their altitude, vegetation, and surface-soil characteristics.

Organic Components and Particle Size Distribution

The primary influences of altitude on soil organic matter deposition and transformations may be expected to arise from differences in vegetation, temperature, and moisture. Artemisia tridentata is the principal overstory shrub species throughout the altitudinal sampling range whereas the grass understory consists primarily of Bromus tectorum at elevations below $<180$ $\mathrm{m}$, Poa secunda at approximate 1 y 180 to $270 \mathrm{~m}$, and Agropyron spicatum at elevations above $270 \mathrm{~m}$. 
TABLE 5a. Representative Soils of the Arid Land Ecology Reserve (after Wildung et a1., 1971).

\begin{tabular}{llll}
\hline \multicolumn{1}{c}{ Classification } & & \\
\hline 7th Approximation & $\begin{array}{c}\text { Great Soil } \\
\text { Group }\end{array}$ & $\begin{array}{l}\text { Vegetative } \\
\text { Understory }\end{array}$ & Elevation \\
\hline $\begin{array}{l}\text { Lithic Haplustoll } \\
\text { (Lickskillet 1) }\end{array}$ & Lithosol & Agropyron & 940 \\
$\begin{array}{l}\text { Andic Aridic Haplustoll } \\
\text { (Ritzville sil) }\end{array}$ & Brown & Agropyron & 445 \\
$\begin{array}{l}\text { Andic Mollic Camborthid } \\
\text { (Warden sl) }\end{array}$ & Sierozem & Poa & 190 \\
$\begin{array}{l}\text { Typic Torripsammet } \\
\text { (Burbank ls) }\end{array}$ & Regosol & Broms & 155 \\
\hline
\end{tabular}

TABLE 5b. Characteristics of Representative Soils of the Arid Land Ecology Reserve (after Wildung et al., 1971).

\begin{tabular}{|c|c|c|c|c|c|c|}
\hline \multirow[b]{2}{*}{ Classification } & \multirow[b]{2}{*}{$\mathrm{pH}$} & \multicolumn{4}{|c|}{ Contents $(a)$ of } & \multirow[b]{2}{*}{$\begin{array}{c}\text { CEC } \\
\text { at } \\
\mathrm{pH} 7.0\end{array}$} \\
\hline & & $\begin{array}{l}\text { Organic } \\
\text { Carbon }\end{array}$ & $\begin{array}{l}\text { Sand } \\
\left(>50_{\mu}\right)\end{array}$ & $\begin{array}{c}\text { Silt } \\
(50 \text { to } \\
2 \mu)\end{array}$ & $\begin{array}{l}\text { Clay } \\
(<2 \mu) \\
\end{array}$ & \\
\hline & & & \multicolumn{2}{|c|}{$\%$} & & $\mathrm{meq} / 900 \mathrm{~g}$ \\
\hline Lickskillet 1 & 6.2 & 3.62 & 42.6 & 41.1 & 16.3 & 40.3 \\
\hline Ritzville sil & 6.2 & 0.66 & 23.3 & 64.1 & 12.6 & 22.5 \\
\hline Warden sl & 7.0 & 0.52 & 55.5 & 34.1 & 10.4 & 18.1 \\
\hline Burbank Is & 6.9 & 0.46 & 76.8 & 16.8 & 6.4 & 11.2 \\
\hline
\end{tabular}

(a) Percent organic carbon based on total soil, other values on total minerals. 
The carbon content of the intact soils generally decreases with decreased elevation likely as a result of (1) decreased plant understory biomass and soil deposition of organic matter with decreased rainfall and (2) increased soil organic matter degradation rate with increased mean annual temperature (Rickard, 1968; Hinds and Thorp, 1969). The decreased soil carbon content with decreased elevation may also reflect a smaller quantity of aromatic substances, resistant to microbial decomposition, deposited on the soil as lignin in associated grass tissues. Investigations by Wildung et al. (1968) have shown that the 1 ignin content of mature Agropyron, Poa and Bromus, tissue amounted to $4.5,3.6$, and $2.7 \%$ respectively.

The soil clay contents range from 6.4 to $16.3 \%$ and also decrease downslope. Cation exchange capacities (CEC) of the Lickskillet, Ritzville, Warden, and Burbank soils at pH 7.0 are 40.3, 22.5, 18.1, and $11.2 \mathrm{meq} / 100 \mathrm{~g}$, respectively, thereby increasing with decreased soil clay and organic carbon content. The observed increase in CEC results from increased surface area and solid-phase coulombic charge associated with higher concentrations of colloidal mineral and organic matter.

The carbon which may be removed from soil as humic colloids or accessory (alcohol/benzene soluble) components ranges from 4.0 to 16.5 and 1.7 to $7.8 \%$, respectively (Wildung et al., 1968). On a total weight basis, yields of sodium hydroxide and alcohol/benzene soluble materials from soils are less than $0.5 \%$ and therefore comparisons of the yields of soil extractives would be tenuous. The carbon, hydrogen and nitrogen contents of isolated soil humic colloids were quite similar and range from 54.3 to 58.1, 5.7 to 6.2, and 4.8 to $5.8 \%$, respectively (Table 6 ). These data are comparable with values reported by other investigators (Kononova, 1966; Wildung et al., 1970) for humic components from a wide variety of mineral soils developed under different climatic conditions.

Although elemental compositions of the humic colloids were similar, the Warden sl and Ritzville sil humic acids exhibited signficantly higher carbon and nitrogen contents and lower carbon/nitrogen ratios than the Burbank humic colloids, whereas the Lickskillet humic colloid gave intermediate 
TABLE 6. Elemental Composition and Cation Exchange Capacity of Humic Acids from Representative Arid Land Ecology

Reserve Soils (after Wildung, et. al., 1971)

\begin{tabular}{|c|c|c|c|c|c|c|c|c|}
\hline \multirow{2}{*}{$\begin{array}{l}\text { So } 1 \text { Humic } \\
\text { Acids }\end{array}$} & \multirow[b]{2}{*}{ Ash } & \multicolumn{3}{|c|}{ Contents of } & \multicolumn{2}{|c|}{ Ratio of } & \multicolumn{2}{|c|}{$\begin{array}{l}\text { Cation } \\
\text { Exchange } \\
\text { Capacity }\end{array}$} \\
\hline & & Carbon & Hydrogen & Nitrogen & Nitrogen & Hydrogen & 4.0 & 7.0 \\
\hline & $\%$ & $\%$ of $d r$ & $y$, ash-fr & e sample & & & meq/ & $100 \mathrm{~g}$ \\
\hline Lickskillet 1 & 1.2 & 56.6 & 5.7 & 5.3 & 10.8 & 9.9 & 117 & 200 \\
\hline Ritzville sil & 2.9 & 57.8 & 6.1 & 5.8 & 9.9 & 9.4 & 132 & 190 \\
\hline Warden sl & 1.6 & 58.1 & 6.2 & 5.6 & 10.3 & 9.3 & 196 & 260 \\
\hline Burbank is & 1.9 & 54.3 & 6.0 & 4.8 & 11.4 & 9.1 & 93 & 270 \\
\hline
\end{tabular}

values (Table 6). The carbon/hydrogen ratios were also similar ranging from 9.1 (Burbank 1s) to 9.9 (Lickskillet 1).

Cation exchange capacities of soil humic colloids (Table 6) at pH 4.0 and 7.0 ranged from 76 to 196 and 190 to $270 \mathrm{meq} / 100 \mathrm{~g}$, respectively. The CEC of the Warden humic acid amounted to over twice that of the humic acid at $\mathrm{pH}$ 4.0. The Ritzville and Lickskillet were intermediate between the Warden and the Burbank humic acids at the low pH. At pH 7.0, the Warden and Burbank samples gave the highest CEC; the Ritzville and Lickskillet humic acids exhibited the lowest values.

The comparatively high CEC of the Warden humic acid, particularly at $\mathrm{pH}$ 4.0, may reflect the high CEC of the associated Poa lignin at 7.0 (Wildung et a1., 1968). It may be speculated that the Poa lignin contains a larger number of acidic groups ionizing near $\mathrm{pH} 7.0$ than the other lignins, and during soil decomposition, these groups are strengthened, resulting in a humic acid comparatively higher in CEC at $\mathrm{pH} 4.0$.

Mineral Components

The major minerals present in the clay fraction of the ALE Reserve soils are given in Table 7 . The minerais reflect the varied parent materials of the region and, to a lesser extent, the effect of different mineral 
TABLE 7. Mineralogical Analys is of Representative Soils of the Arid Land Ecology Reserve (after Routson et al., 1975)

\begin{tabular}{|c|c|c|c|c|}
\hline Soil & Lickskillet & Ritzville & Warden & Burbank \\
\hline \multicolumn{5}{|c|}{ Fine Clay $(<0.2 \mu)$} \\
\hline Montmorillonite & M & $M$ & M & $M$ \\
\hline Illite & M & & m & m \\
\hline Kaolinite & & $\mathrm{m}$ & $t$ & $m$ \\
\hline Quartz & $\mathrm{m}$ & $t$ & $t$ & $\mathrm{~m}$ \\
\hline Vermiculite & $M$ & & & M \\
\hline Mica & & m & & \\
\hline Interstratified & $t$ & & & $t$ \\
\hline \multicolumn{5}{|c|}{ Coarse Clay $(0.2-2 \mu)$} \\
\hline Montmorillonite & M & M & $M$ & $M$ \\
\hline Illite & $M$ & & m & $\mathrm{m}$ \\
\hline Kaolinite & $\mathrm{m}$ & $\mathrm{m}$ & $t$ & $\mathrm{~m}$ \\
\hline Quartz & $\mathrm{m}$ & $\mathrm{m}$ & $\mathrm{m}$ & $\dot{m}$ \\
\hline Feldspar & & $t$ & $t$ & $\mathrm{~m}$ \\
\hline Vermiculite & $M$ & & & $\mathrm{~m}$ \\
\hline Mica & & $\mathrm{m}$ & & \\
\hline Interstratified & $t$ & & & $t$ \\
\hline
\end{tabular}

weathering rates and processes. Weathering processes probably do not serve as a major control on the clay mineral composition of these relatively young soils. Where larger surface areas facilitate more intensive weathering conditions, quartz and feldspar in the finer particle size fractions have normally weathered to extinction. The persistence of quartz and feldspar in the clay fractions of the soils of the ALE Reserve indicates that, in genera], the combined effect of weathering intensity and time have failed to 
qualitatively alter the mineralogy of the soil clay fraction. In contrast, major differences exist in the quantities of oxidic iron, aluminum, and manganese in these soils (Table 8). Citrate-bicarbonate-dithionite is generally considered to extract inorganic oxidic iron and aluminum, including crystallized oxides, amorphous-aged hydrous oxides and amorphous gel hydrous oxides (Bascomb, 1968). There was a general increase in citratebicarbonate-dithionite extractable iron and aluminum downslope from the Lickskillet to the Burbank 1s, generally corresponding to decreased clay content (Table 5). This likely reflected the increased weathering rate and reactive surface area of the soils downslope. The potassium hydroxide extractant was used to compare extractable aluminum and silicon. The ratios of aluminum to silicon ranged from 2.8 to 9.7 and the soils would be classified as "very siliceous aluminosilicate" types (Jackson 1969). Values exceeding 4.5 are rare in the literature. Oxidic manganese did not exhibit altitudinal trends but the coarse-textured Burbank is was among the lowest as in the case of the other elements.

TABLE 8. Quantity of 0xidic Iron, Aluminum, Manganese and silicon in Representative Soils of the Arid Land Ecology Reserve (unpublished)

\begin{tabular}{|c|c|c|c|c|c|}
\hline \multirow{3}{*}{ So il } & \multicolumn{5}{|c|}{ Extractant and Element } \\
\hline & \multicolumn{2}{|c|}{$\begin{array}{r}\text { Citrate-bicarbonate } \\
\text { dithionite(a) }\end{array}$} & \multicolumn{2}{|c|}{ Potassium hydroxide $(a)$} & $\begin{array}{c}\text { Acidic } \\
\text { hydroxylamine }(b)\end{array}$ \\
\hline & $\begin{array}{l}\text { Iron } \\
\left(\mathrm{Fe}_{2} \mathrm{O}_{3}\right)\end{array}$ & $\begin{array}{l}\text { Al uminum } \\
\left(\mathrm{Al}_{2} \mathrm{O}_{3}\right)\end{array}$ & $\begin{array}{l}\text { Aluminum } \\
\left(\mathrm{Al}_{2} \mathrm{O}_{3}\right)\end{array}$ & $\begin{array}{l}\text { Silicon } \\
\left(\mathrm{SiO}_{2}\right)\end{array}$ & $\begin{array}{l}\text { Manganese } \\
\left(\mathrm{MnO}_{2}\right)\end{array}$ \\
\hline & ---- & ---- & $---\mu g / g$ & ---- & $-\cdots-\cdots$ \\
\hline Lickskillet 1 & 2,900 & 265 & 300 & 2,440 & 410 \\
\hline Ritzville sil & 2,040 & 170 & 250 & 2,420 & 510 \\
\hline Warden sl & 2,040 & 94 & 250 & 690 & 710 \\
\hline Burbank 1s & 1,440 & 94 & 210 & 810 & 240 \\
\hline
\end{tabular}
(a) Jackson (1969)
(b) Chao (1972) 


\section{Soil Temperature and Water Content}

Soil temperature and moisture have been measured on a seasonal basis on the intensive study site. In addition, water retentivity, a measure of water holding capacity and plant available water has been determined over the range of ALE Reserve soils.

The soil temperature and moisture were measured during 1971 and 1972 (Wildung et a1. 1975). With the exception of several sharp decreases during rainstorms, soil temperature generally exhibited a gradual increase from $7^{\circ} \mathrm{C}$ in April to $31^{\circ} \mathrm{C}$ near the end of July 1971 (Figure 4). This temperature was maintained throughout most of August. By September 1, 1971, the soil temperature had decreased to $19^{\circ} \mathrm{C}$ and it continued to decrease to a low of $0.5^{\circ} \mathrm{C}$ in February 1972. A similar temperature cycle occurred in 1972, except that the maximum recorded temperature $\left(24^{\circ} \mathrm{C}\right.$ in August) was lower than 1971.

Soil water content was inversely correlated $(r=0.67 ; P<0.01)$ with soil temperature during the monitoring period. Soil water content generally decreased in the spring of 1971 from approximately 10\% (13 bar suction) in April to summer lows of less than $2 \%$ ( 88 bar suction). Increases in soil

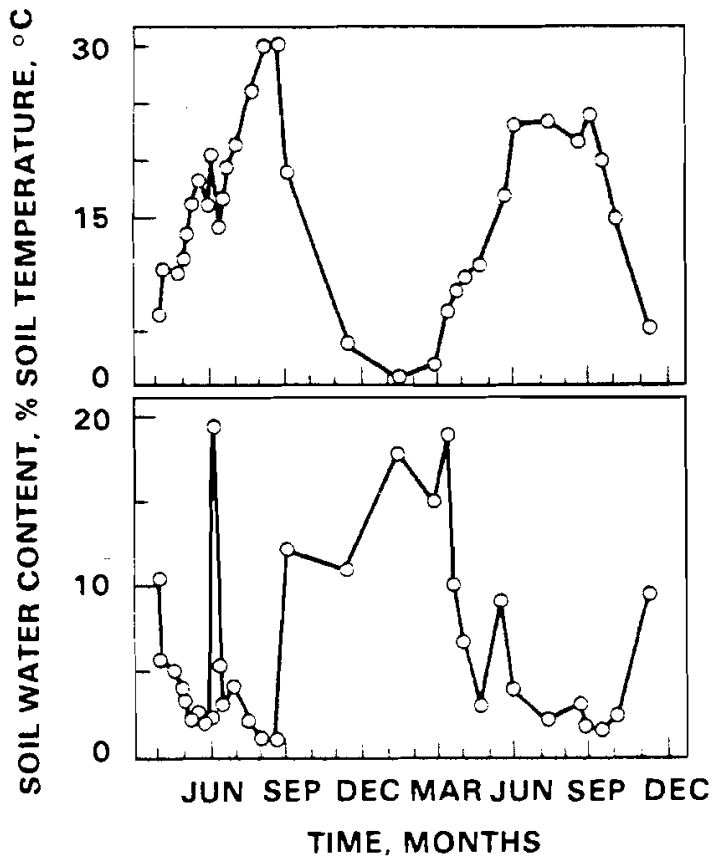

FIGURE 4. Seasonal Changes in Soil Temperature and Water Content in the Ritzville sil (after Wildung et al., 1975) 
water content occurred with fall rains, and water content reached annual maxima (15-20\%) in the winter of 1971 and early spring of 1972. Maximum water contents were less than "field water capacity" or water retentivity at 0.3 bar suction (28\%). A similar pattern of events occurred in 1972. With the occurrence of rainfall in June 1971 and May 1972, there were marked increases in soil water content. However, surface soil water contents decreased rapidly after initial increases due to downward water movement and evapotranspiration processes. Water did not infiltrate below $7 \mathrm{dm}$.

Moisture retention (Figure 5 ) is a function of soil structure and organic carbon content (Table 5) with finer textured, higher organic matter soils maintaining the largest quantities of water at highest tension levels.

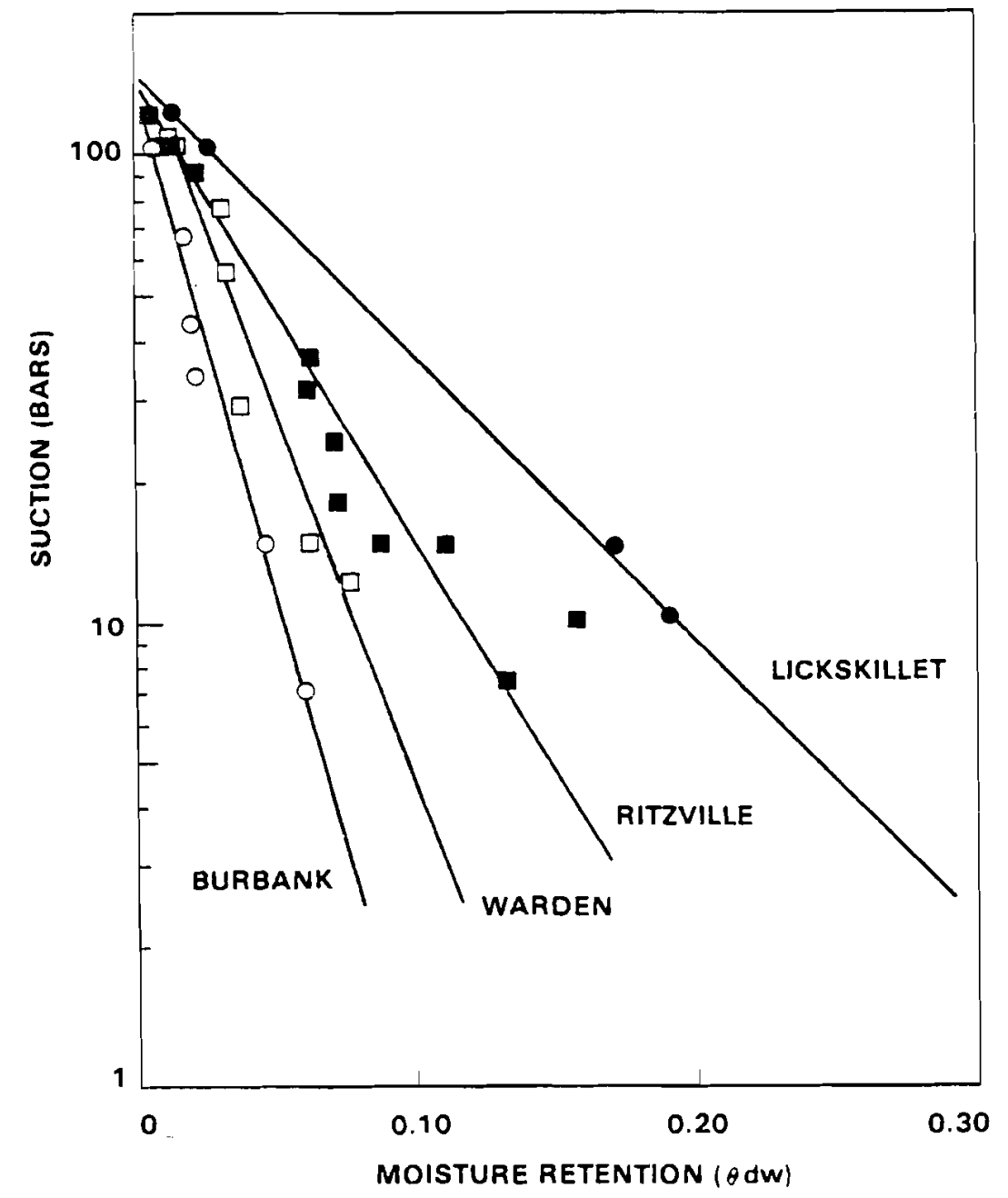

FIGURE 5. Moisture Tension Curves for Soils of the Arid Land Ecology Reserve (unpublished) 


\section{REFERENCES}

Bascomb, C. L. 1968. Distribution of pyrophosphate-extractable iron and organic carbon in soils of various groups. J. of Soil Sci. 19(2): 251-268.

Chao, T. T. 1972. Selective dissolution of manganese oxides from soils and sediments with acidified hydrorglamine hydrochloride. Soil Sci. Soc. Amer. Proc. 36(5): 764-768.

Hajek, B. F. 1966. Soil Survey, Hanford Project in Benton County Washington. BNWL-243. Battel le, Pacific Northwest Laboratories, Richland, WA.

Hinds, W. T., and J. M. Thorp. 1969. Biotic and Abiotic Characteristics of the Microclimatological Network on the Arid Lands Ecology Reserve. BNWL-SA-2733. Battelle, Pacific Northwest Laboratories, Richland, WA.

Jackson, M. L. 1969. Soil Chemical Analysis-Advanced Course. Published by Author.

Kocher, A. E., and A. T. Strahorn. 1916. Soil Survey of Benton County, Washington. U.S. Department of Agriculture, Bureau of Soils.

Kononova, M. M. 1966. Soil Organic Matter. Permagon Press, New York, NY.

Rasmussen, J. J. 1971. Soil Survey of Benton County Area, Washington. U.S. Department of Agriculture Soil Conservation Service and Washington Agricultural Experiment Station.

Richard, W. H. 1968. Field observations on the altitudinal distribution of the side-blotched lizard. Northwest Sci. 42:161-164.

Strahorn, A. T. 1929. Soil Survey (Reconnaissance) of the Columbia Basin Area, Washington. U.S. Department of Agriculture, Bureau of Chemistry and Soils.

U.S. Department of Agriculture, Agricultural Experiment Stations of the Western State Land-Grant Universities and Colleges and the Soil Conservation Service. 1964. Soils of the Western United States. Washington State University, Pul1man, WA.

Wildung, R. E., B. F. Hajek and K. R. Price. 1968. Chemical characterizations of the arid soil organic fraction. Comparative chemical properties of plant legnins and soil humic acids. BNWL-982. Battelle, Pacific Northwest Laboratories, Richland, WA.

Wildung, R. E., J. W. Blaylock, R. C. Routson and A. R. Gahler. 1970. Seasonal distribution of $P$ in total, inorganic and organic $P$ fractions of eutrophic lake sediments. In: Agronomy Abstracts ASA, SSSA and CSSA Annual Meetings. Tucson, AZ, August 23-27, 1970. 
Wildung, R. E., B. F. Hajek and K. R. Price. 1971. Chemical properties of the arid soil organic fraction. Northwest Sci. 45(2):73-79.

Wildung, R. E., T. R. Garland and R. L. Buschbom. 1975. The interdependent effects of soil temperature and water content on soil respiration rate and plant root decomposition in arid grassland soils. Soil Biol. Biochem. 7: $373-378$. 


\section{ACKNOWLEDGMENTS}

Grateful appreciation is extended to T. R. Garland and R. C. Routson for assistance in interpretation and to Naomi Sherer for graphics and editing. 



\section{DISTRIBUTION}

No. of

Copies

$\underline{\text { OFFSITE }}$

1 A. A. Churm

ERDA Patent Group

9800 South Cass Avenue

Argonne, IL 60439

27 Technical Information Center

1 R. L. Watters

Division of Biomedical and

Environmental Research

U.S.E.R.D.A.

Washington, DC 20545

1 R. E. Franklin

Division of Biomedical and

Environmental Research

U.S.E.R.D.A.

Washington, DC 20545

1 R. Dahlman

Division of Biomedical and Environmental Research

U.S.E.R.D.A.

Washington, DC 20545

1 J. Swinebroad

Division of Biomedical and Environmental Research

U.S.E.R.D.A.

Washington, DC 20545

1 B. Frazier

405 Johnson Hall

Washington State University

Pullman, WA 99164

$1 \quad$ F. Ugolini

College of Forest Resources

University of Washington

Seattle, WA 98195
No. of

Copies

ONS ITE

1 ERDA Richland Operations

Office

H. E. Ransom

2 Rockwell Hanford Operations

K. R. Price

V. A. Uresk

49 Battelle-Northwest

T. W. Ambrose

W. J. Bair

D. A. Cataldo

D. B. Cearlock

J. F. Cline

T. R. Garland

W. T. Hinds

D. E. Olesen

D. Paine

D. Rai

L. A. Rancitelli

W. H. Rickard

L. E. Rogers

R. C. Routson

R. G. Schreckhise

G. A. Sehmel

R. J. Serne

N. M. Sherer

J. A. Strand

J. M. Thorp

W. L. Templeton

D. W. Uresk

B. E. Vaughan

R. E. Wildung (20)

Technical Information Files (5)

Technical Publications 


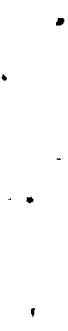

